\title{
Development of bioassay system for evaluation of materials for personal protective equipment (PPE) against toxic effects of ionizing radiations
}

\author{
Masatake YAMAUCHI ${ }^{1 *}$ and Sachiko SAKUMA ${ }^{1}$ \\ ${ }^{1}$ Department of Basic Medical Sciences for Radiation Damages, National Institute of Radiological Sciences, Japan \\ Received August 5, 2017 and accepted October 2, 2017 \\ Published online in J-STAGE October 11, 2017
}

\begin{abstract}
Health effects caused by ionizing radiations raise considerable concern among general public and radiation workers. To estimate ability of personal protective equipment (PPE) materials that reduce toxic effects of ionizing radiations, we developed an experimental bioassay system using Chinese Hamster V79 cells. The system developed here distinguished the biological effectiveness of $X$-ray that was significantly affected by elements composed of shielding materials. Survival of the cells exposed to sub-lethal dose of $\mathrm{X}$-ray was enhanced more than 2 times when the $\mathrm{X}$-ray was filtrated by a lead plate. Also filtration of the $\mathrm{X}$-ray with a tungsten plate enhanced the cell survival more than three times. These results suggested the colony assay system developed here was useful for examination of the biological effectiveness of X-ray and the ability of PPE materials reducing the toxic effects caused by ionizing radiations.
\end{abstract}

Key words: Ionizing radiation, Colony assay, Bioassay, V79 cells, PPE, Health effect

Concern over the health effect of ionizing radiation began right after the discovery of X-ray in $1895^{1)}$. Two general principles for radiation protection are to prevent acute exposure and to limit chronic exposure to acceptable levels ${ }^{2}$. Follow-up study of atomic bomb survivors exposed at Hiroshima and Nagasaki in 1945 showed that very high dose of acute radiation exposure have increased cancer risks among general public ${ }^{3,4)}$.

It is important to protect human health from unnecessary exposure to ionizing radiation and to have the benefits through various applications such as uses in medicine, industry, agriculture and research. Frequent medical use of X-ray raises significant concern among general public. Annual number of medical use of X-ray devices has been reported to have positive correlation with increase of risk causing cancer incidences ${ }^{5}$.

*To whom correspondence should be addressed.

E-mail: yamauchi.masatake@qst.go.jp

(C)2017 National Institute of Occupational Safety and Health
Lead plate is commonly used to shield X-ray in clinics and laboratories, however, shielding is not usually perfect and small amount of X-ray penetrate through the shield. Penetrated X-ray raises considerable concern among general public and radiation workers. For development of PPE materials shielding toxic effects of ionizing radiations, establishment of a new evaluation system based on bioassay is necessary, since physical shielding of ionizing radiations with high penetration ability, such as X-ray and gamma ray, is practically difficult. We, however, have realized that it is possible to reduce the biological effectiveness of high energy photons by filtration technique in our preliminary experiments. When mammalian cells, including Chinese hamster V79 cells and human normal fibroblast cells, were exposed to the high energy photons such as X-ray and gamma ray with or without shielding materials made of metal, such as lead, steel, or tungsten, survival rate of the exposed cells were significantly affected (data not shown). These observations lead us to the systematic examination described in this study. 
To investigate the biological effect of ionizing radiations that penetrated a metal plate shield, we have developed the colony assay system using Chinese hamster V79 cells. V79 cells have higher than $80 \%$ of a plating efficiency and a generation time of 12 to 14 hours, and have been employed in many toxicological bioassay experiments ${ }^{6,7)}$. We speculated the high energy photons that penetrated metal plates made of lead $(\mathrm{Pb})$ or tungsten $(\mathrm{W})$ may be biologically less effective, since highly interactive photons would be filtrated by a metal shield. Here we demonstrate the usefulness of the bioassay system using V79 cells for evaluating the biological effectiveness of X-ray with or without filtration. Changes in the biological effectiveness of $\mathrm{X}$-rays were clearly distinguished by the bioassay system described here.

Chinese hamster V79 cells were maintained in growth medium composed of MEM medium (Thermo Fischer Scientific, Japan) containing $10 \%$ of foetal bovine serum (FBS, Biowest, France), using plastic petri dishes (BD Falcon 353003, USA). Cells were cultured using $\mathrm{CO}_{2}$ incubator (Tabai Espec, Japan) in the atmosphere containing $5 \% \mathrm{CO}_{2}$ and $100 \%$ humidity.

Exponentially growing cells in a petri dish were washed with phosphate-buffered saline (PBS), treated with $2.5 \%$ trypsin, and suspended in $10 \mathrm{ml}$ of the growth medium. 1 $\mathrm{ml}$ of cell suspension containing approximately $10^{6}$ cells was aliquoted to $15 \mathrm{ml}$ test tubes (Biologix 10-9152, USA). X-ray was generated using PANTAK HF320-S X-ray System (Shimadzu, Japan) at the energy of $200 \mathrm{kV}-20 \mathrm{~mA}$. Generated X-ray was filtrated by using $0.5 \mathrm{~mm}$ cupper $(\mathrm{Cu})+0.5 \mathrm{~mm}$ aluminium (Al) filter to remove secondary electrons and low energy photon in the braking X-ray generated. 10 Gy of X-ray was exposed to the cell suspension at the distance of $300 \mathrm{~mm}$. For shielding, either a 1 $\mathrm{mm}$ thick $\mathrm{Pb}$ plate or a $1 \mathrm{~mm}$ thick $\mathrm{W}$ plate was used and placed between the irradiation port and the cell suspension. Dose rate of X-ray was monitored by using an ionization chamber and the exposed dose was calculated as a product of dose rate and exposure time.

Dose rate of X-ray without shield was 3.56 Gy per minute. With $1 \mathrm{~mm}$ thick lead plate, the dose rate was reduced to 0.19 Gy per minute, compared to the dose rate without the shield. With $1 \mathrm{~mm}$ thick tungsten plate, it was reduced to 0.29 Gy per minute. After X-ray exposure, the cell suspension was diluted with the growth medium and plated to petri dishes. Each exposed cell suspension was diluted with growth medium and $10^{2}$ to $10^{3}$ cells were plated to three petri dishes, respectively. Number of colonies formed after one week was counted manually. The results were
Table 1. Summary of the experimental results examining the correlation between the shielding material and cell survival. $\mathrm{Pb}$ represents lead and $W$ represents tungsten

\begin{tabular}{ccccc}
\hline $\begin{array}{c}\text { dose } \\
(\text { Gy })\end{array}$ & $\begin{array}{c}\text { dose rate } \\
(\text { Gy/min })\end{array}$ & $\begin{array}{c}\text { shielding } \\
\text { material }\end{array}$ & $\begin{array}{c}\text { number of colony } \\
(\text { Mean } \pm \text { SE) }\end{array}$ & \% survival \\
\hline 0 & 0 & & $677 \pm 6.2$ & 100 \\
10 & 3.56 & no shield & $40 \pm 1.5$ & 6 \\
10 & 0.29 & $1 \mathrm{~mm} \mathrm{~Pb}$ & $87 \pm 5.2$ & 13 \\
10 & 0.19 & $1 \mathrm{~mm} \mathrm{~W}$ & $148 \pm 4.5$ & 22 \\
\hline
\end{tabular}

summarized in Table 1.

Without X-ray exposure, the cells formed 688,674 , and 689 colonies on control plates, respectively. It was calculated to be 677 on average with standard error of the mean of 6.2. The same dilution of the cell suspension exposed to 10 Gy of X-ray without shield formed 37, 42, and 40 colonies, respectively. It was calculated to be 40 colonies on average with standard error of the mean of 1.5 , meaning the survival of the exposed cells reduced to $5.9 \%$ by the sublethal dose of X-ray exposure. The cell suspension exposed to the equivalent dose of X-ray but filtrated with a $1 \mathrm{~mm}$ thick $\mathrm{Pb}$ plate formed 80, 83, and 97 colonies, respectively. It was calculated to be 87 colonies on average with standard error of the mean of 5.2, meaning the survival of the exposed cells were enhanced more than 2 times. Also the cells exposed to 10 Gy of X-ray filtrated with a $1 \mathrm{~mm}$ thick W plate formed 152, 139, and 153 colonies, respectively. It was calculated to be 148 colonies on average with standard error of the mean of 4.5 , showing more than 3 times enhancement of cell survival compared to the experiment carried out without a shielding plate. Thus, the X-ray filtrated with metal plates seemed to be biologically less effective than the non-filtrated X-ray, although the dose of $\mathrm{X}$-ray exposed to the cells were equivalent to the one without filtration.

There was a possibility that the difference in the biological effectiveness observed in the above experiments may be caused by the dose rate of X-ray exposure. To examine the correlation between the dose rate and the cell survival, the cells were exposed to 0,3 , and 10 Gy of X-ray at the distance of $320 \mathrm{~mm}$ and $960 \mathrm{~mm}$. Dose rate was $2.72 \mathrm{~Gy} /$ min at $320 \mathrm{~mm}$, and was $0.28 \mathrm{~Gy} / \mathrm{min}$ at $960 \mathrm{~mm}$. The results did not show clear correlation between the dose rate of X-ray and the cell survival, as shown in Table 2. On the control plates without X-ray exposure, the number of colony formed by using $10^{5}$ times dilutions were 159,151 , and 142 , respectively. It was calculated to be 151 on average with standard error of the mean of 4.9. At the dose of 
Table 2. Summary of the experimental results examining the correlation between the dose rate and the cell survival

\begin{tabular}{|c|c|c|c|c|c|}
\hline \multirow{2}{*}{$\begin{array}{l}\text { dose } \\
\text { (Gy) }\end{array}$} & \multirow{2}{*}{$\begin{array}{c}\text { distance } \\
(\mathrm{mm})\end{array}$} & \multirow{2}{*}{$\begin{array}{l}\text { dose rate } \\
\text { (Gy/min) }\end{array}$} & \multicolumn{2}{|c|}{$\begin{array}{l}\text { number of colony } \\
\quad(\text { Mean } \pm \text { SE })\end{array}$} & \multirow[t]{2}{*}{$\%$ survival } \\
\hline & & & $\times 10^{4}$ dilution & $\times 10^{5}$ dilution & \\
\hline 0 & & 0 & - & $151 \pm 4.9$ & 100 \\
\hline 3 & \multirow{2}{*}{320} & \multirow{2}{*}{2.72} & 一 & $82 \pm 6.4$ & 54 \\
\hline 10 & & & $173 \pm 8.2$ & - & 11 \\
\hline 3 & \multirow{2}{*}{960} & \multirow{2}{*}{0.28} & - & $92 \pm 8.5$ & 61 \\
\hline 10 & & & $131 \pm 4.7$ & - & 9 \\
\hline
\end{tabular}

3 Gy, the cells exposed to X-ray at the lower dose rate of $0.28 \mathrm{~Gy} / \mathrm{min}$ formed 109,81 , and 87 colonies, respectively. It was calculated to be 92 colonies on average with standard error of the mean of 8.5 in $10^{5}$ times dilutions. The cells exposed at the higher rate of $2.72 \mathrm{~Gy} / \mathrm{min}$ formed 81 , 94, and 72 colonies, respectively. It was calculated to be 82 colonies on average with standard error of the mean of 6.4, thus the lower dose rate in X-ray exposure resulted in slightly better cell survival rate. The result, however, was opposite when $10 \mathrm{~Gy}$ of X-ray was exposed to the cells at two different dose rates. When the cells were exposed to 10 Gy of X-ray, $10^{4}$ times dilutions of the higher dose rate group formed 166, 163, and 189 colonies, respectively. It was calculated to be 173 colonies on average with standard error of the mean of 8.2, whereas the same dilution of the lower dose rate group formed 130, 140, and 124 colonies, respectively. It was calculated to be 131 colonies on average with standard error of the mean of 4.7. The result of the 10 Gy exposure experiment showed slightly lower survival rate in the lower exposure rate group. We, therefore, concluded that the differences in number of colonies formed were not significant, and that the clear correlation between the dose rate of X-ray exposure and the cell survival was not observed. We also concluded that the results obtained in the previous experiments showed the significant differences in the biological effectiveness of the X-rays with or without filtration.

To examine the usefulness of bioassay system for evaluation of materials against toxic effect of ionizing radiation, we attempted to detect the changes in the biological effect of X-ray penetrated through a metal plate shield in this study. Cell culture experiment sometimes may not reflect the toxicological effects on individual animals, however, it is cost effective and especially suitable for primary screening purposes. Accumulation of experimental results using Chinese Hamster V79 cells enabled us to compare the biological effects caused by various substances, including ion- izing radiations.

The results obtained in this study showed the biological effectiveness of X-ray was significantly reduced when $\mathrm{X}$-ray was filtrated with a metal plate, as shown in Table 1.

These results suggested that the bioassay system developed in this study would be useful for evaluating materials shielding toxic effect of ionizing radiations. Since perfect shielding of ionizing radiations with highly penetrative property, such as X-rays and gamma rays, is very difficult, our second best attempt would be useful for developing practical PPE materials reducing toxic effects caused by ionizing radiations. At this moment, we do not have proper explanation for the reduction of toxic effects of the filtrated X-ray. At least, the energy of the filtrated X-ray was sufficiently high to be detected as ionizing radiation, since it was detected by the ionization chamber. Further study examining the correlation of biological effectiveness between the X-rays at different energy levels may be informative for understanding the phenomenon observed in this study.

\section{Acknowlegements}

We would like to express my many thanks to Dr Yoshiya FURUSAWA in National Institute of Radiological Sciences for fruitful discussions. This research work was supported by JSPS KAKENHI Grant Number 15H01789.

\section{References}

1) Daniel J (1896) The X-rays. Science 3, 562-3. [Medline] [CrossRef]

2) Sources, Effects and Risks of Ionizing Radiation (2016) UNSCEAR 2016 Report, http://www.unscear.org/docs/ publications/2016/UNSCEAR_2016_Report.pdf Accessed on 14th July 2017.

3) Grant EJ, Brenner A, Sugiyama H, Sakata R, Sadakane A, Utada M, Cahoon EK, Milder CM, Soda M, Cullings HM, Preston DL, Mabuchi K, Ozasa K (2017) Solid Cancer Incidence among the Life Span Study of Atomic Bomb Survivors: 1958-2009. Radiat Res 187, 513-37. [Medline] [CrossRef]

4) Cahoon EK, Preston DL, Pierce DA, Grant E, Brenner AV, Mabuchi K, Utada M, Ozasa K (2017) Lung, Laryngeal and Other Respiratory Cancer Incidence among Japanese Atomic Bomb Survivors: An Updated Analysis from 1958 through 2009. Radiat Res 187, 538-48. [Medline] [CrossRef]

5) Berrington de González A, Darby S (2004) Risk of cancer from diagnostic X-rays: estimates for the UK and 14 other countries. Lancet 363, 345-51. [Medline] [CrossRef]

6) Bradley MO, Bhuyan B, Francis MC, Langenbach R, 
Peterson A, Huberman E (1981) Mutagenesis by chemical agents in V79 chinese hamster cells: a review and analysis of the literature. A report of the Gene-Tox Program. Mutat Res 87, 81-142. [Medline] [CrossRef]

7) Sakai A, Iwase Y, Nakamura Y, Sasaki K, Tanaka N, Umeda
M (2002) Use of a cell transformation assay with established cell lines, and a metabolic cooperation assay with V79 cells for the detection of tumour promoters: a review. Altern Lab Anim 30, 33-59. [Medline] 